\title{
УКРАЇНСЬКЕ ПИТАННЯ НА СТОРІНКАХ ГАЗЕТИ “ХЛІБОРОБ”
}

\author{
ЛюдмиЛа БАБЕНКО \\ Полтавський національний педагогічний університет \\ імені В. Г. Короленка \\ кафедра історії України \\ вул. Остроградського, 2, Полтава, 36000, Україна \\ e-mail: babenko_clio@ukr.net
}

\begin{abstract}
Висвітлено події в Україні, пов'язані з виникненням україномовної преси на початку XX ст. Акцентується увага на газеті “Хлібороб” - першій українській газеті на Лівобережній Україні, яка виходила в м. Лубни Полтавської губернії. Показано політику російського самодержавства, спрямовану на заборону національно-визвольного руху й панування цензури, яка й сформувала “українське питання". На сторінках періодики відображено невирішені національно-державні, культурно-освітні, соціяльно-економічні проблеми українських земель у складі Російської імперії. Проаналізовано зміст і політичну спрямованість газети "Хлібороб", роль ії видавців братів Володимира та Миколи Шеметів у пропаганді суспільно-політичних ідеалів національновизвольного руху.

Ключові слова: газета “Хлібороб”, Володимир Шемет, Микола Шемет, Лубни, Полтавська губернія, преса, цензура.
\end{abstract}

Сучасне цивілізоване суспільство використовує безліч комунікативних технологій, котрі забезпечують потреби й виклики соціюму в громадськополітичній, культурно-освітній та інших сферах. В умовах демократії дієвим інструментом реалізації громадянських свобод залишається преса, яка зазвичай $\epsilon$ базовим рушієм свободи слова. Вона відіграє роль ефективного комунікативного засобу лише тоді, коли використовує мову народу, якому мають бути донесені певні ідеї. На початку XX ст.. українці були позбавлені права на україномовну пресу, що випливало з загального контексту політики російщення в Російській імперії. Головна ідея студії- висвітлити процес боротьби за відміну заборон українських форм життя в українських землях у складі імперії. Проблема статті - 3'ясувати роль першої україномовної газети в Наддніпрянській Україні "Хлібороб" у згуртуванні українського суспільства в національно-визвольній боротьбі на початку XX ст.

В українській історіографії до проблем революційних подій 1905 р., боротьби українців за національні права, проти цензурних заборон і політичних репресій зверталося чимало істориків. Однак тематичні та методологічні акценти попередніх десятиліть не давали вичерпних відповідей на питання, пов'язані із зародженням й функціонуванням україномовної преси на початку XX ст. Зокрема грунтовно не висвітлено у студіях істориків й видання “Хлібороб”. Тривалий час вважали, що оригінали накладів п'яти чисел газети втрачені. До того ж склалася й певна недооцінка значення періодики як локального, а не всеукраїнського 
характеру. Доречно зазначити, що в радянській довідково-енциклопедичній літературі, на відміну від інших перших українських видань, "Хлібороб" не згадувався ні в 15-му томі “Української Радянської Енциклопедії” (1964), ні в 4-му томі “Радянської Енциклопедії Історії України" (1972) ${ }^{1}$. Вперше про його існування як історичний факт оприлюднив енциклопедичний довідник «Полтавщина» (1992), але стаття там надто лаконічна, щоб зрозуміти весь драматизм боротьби за права українського слова й думки. До того ж, як зазначала В. Жук, краєзнавчі розвідки кінця 1980-их рр. мали відбиток ідеологічноцензурних штампів та оцінок газети іії̈ змісту на кшталт “ліберально-буржуазна", "націоналістична"2.

Поворотним пунктом в акцентуванні уваги на проблемі став рік 2005, коли виповнилося 100 років від часу заснування у Лубнах газети “Хлібороб”. Ця дата стала поштовхом до пошуку нових архівних та опублікованих джерел свідків епохи, вивчення життя і діяльности подвижників українського національновизвольного руху, що стояли біля витоків створення газети - братів Володимира та Миколи Шеметів, проведення наукових конференцій та публікації їх матеріялів. Водночас дослідники, переважно філологи або знавці історії журналістики, зверталися до видання "Хлібороб" здебільшого фрагментарно, згадуючи його серед інших або ж у контексті антиукраїнської політики самодержавства. Серед дослідників варто виділити П. Ротача, В. Жук, В. Ревегука, Т. Пустовіта, М. Тимошика, О. Сидоренка, В. Стрільця, Б. Ванцака, С. Семенко та ін. Відзначимо як певну віху збірник статтей і документів "Потужна сила рідного слова" (2005) до 100-ліття виходу в світ перших україномовних видань Східної України - "Хлібороб” (Лубни, 1905), “Рідний Край” (Полтава, 1905-1907; Київ, 1907-1914; Гадяч, 1914-1916), “Громадська Думка" (Київ, 1905-1906 рр.), "Рада" (Київ, 1906-1914рр.). До збірника увійшли окремі матеріяли 1-го числа та кілька некрологів з 2-го і 3-го чисел “Хлібороба"”. У 2006 р. вийшов збірник "Українська преса початку XX століття як націотворчий чинник", у якому розглянуто загальні проблеми суспільно-комунікативної ролі преси, окремі історичні сюжети, але відсутні статті, присвячені аналізові змісту газети "Хлібороб". Отже, останнє є лакуною в історіографії, яка потребує висвітлити роль газети "Хлібороб” у боротьбі за вирішення українського проблеми в Російській імперії у всій іiі багатогранності через поширення громадськополітичних ідей в українських друкованих засобах масової інформації на початку ХX ст.

Авторка статті безпосередньо використала джерела з теми. Це копії оригіналів чисел 2-5 газети “Хлібороб”, а також кілька редакційних публікацій числа 1 ,

\footnotetext{
${ }^{1}$ Віра Жук, “Українські періодичні видання початку XX ст. (за даними посібників з історії України), Рідний край, № 2 (13), (2005), 132.

${ }^{2}$ Там само, 133.

${ }^{3}$ Вибрані публікації. "Хлібороб” (1905). Редакційні статті, у книзі Потужна сила рідного слова, упоряд. Н.М. Сидоренко, (Полтава: “РІК”, 2005), 18-26.
} 
ISSN 2078-6077. Наукові зошити історичного факультету Львівського університету. 2018-2019. Випуск 19-20. Proceedings of History Faculty of Lviv University. 2018-2019. Issue 19-20.

надрукованих в аналізованому у статті збірнику ${ }^{4}$. Звернувшись до оригінальних джерел, аналізуємо не лише загальноісторичний контекст, але й актуальні завдання національно-визвольної боротьби, суспільно-політичні ідеї прогресивних діячів, питання, які хвилювали різні суспільні верстви тогочасного суспільства та способи, котрими їх намагалися вирішити.

Історичне минуле Наддніпрянської України, до якої історично й географічно належить Полтавщина, на початку XX ст. було тісно інтегроване в суспільнополітичне й економічне життя Російської імперії. Національна політика самодержавства не визнавала права українців на вільне функціонування української мови в освіті, офіційному справочинств, в галузі друкованого слова, що потверджували Валуєвський циркуляр (1863) та Емський указ (1876). До того ж ця політика створила спотворений стереотип і в свідомості селянства про те, що українська мова - “мужицька”, яка не відкриває будь-якої перспективи в майбутньому. Неосвічені й залякані селяни не підтримували прагнення української інтелігенції щодо переходу дітей навчатись рідною мовою, хоча б у народних початкових школах. Наприклад, присутні на зібранні Кременчуцького повітового земства представники від селянських громад під час розгляду питання запровадити українську мову виступили з категоричним запереченням. Вони мотивували своє рішення тим, що їхні діти, не засвоївши “панської”, тобто російської мови, “навіки залишаться мужиками”, не зможуть “вибитися в люди”: вивчитися на "вчителів, попів, фельдшерів" тощо5. Автор монографії також покликається на Євгена Чикаленка, який у своїх спогадах наводить приклад як нехтували рідну мову пересічні селяни, навіть грамотні. Його знайомий лікар М. Левицький дав сторожеві лікарні надруковане українською мовою Євангеліє, але той, сумно похитавши головою, сказав: “Господи! Вже й зі слова Божого сміються"'.

Селянство радше було готове до революційного бунту за перерозподіл землі й поміщицького майна, ніж до клопітного формування національної свідомости. Цей висновок можна підтвердити історичними фактами, які свідчать про спалах селянських повстань на Полтавщині в 1902 р., у яких взяли участь жителі 336 сіл 19 волостей з населенням понад 160 тис. чоловік, які розгромили 74 поміщицькі економії, а заворушення перекинулися й на Харківську губернію. Революційні події 1905-1907 pp. також були позначені численними селянськими повстаннями й робітничими страйками в Полтаві, Кременчуці, Лубнах ${ }^{7}$.

\footnotetext{
${ }^{4}$ Вибрані публікації. “Хлібороб” (1905). Редакційні статті, у книзі Потужна сила рідного слова, упоряд. Н.М. Сидоренко, (Полтава: “РІК”, 2005), 18-26.

${ }^{5}$ Віктор Ревегук, Селянство Полтавщини в добу Украйнської революції 1917-1921 рр., (Полтава: Полтавський літератор, 2017), 18.

${ }^{6}$ Там само, 19.

${ }^{7}$ Полтавщъина. Історичний нарис, відп. за вип. О.М. Пустовгар (Полтава: Дивосвіт, 2005), 177-178.
} 
Отже. потрібен був каталізатор, щоб поширювати національні ідеї, усвідомлювати значення українського слова для консолідації суспільства навколо української проблеми в Російській імперії. ІІЇ суть в тому, що уряд і не думав вирішувати комплекс національно-державних, культурно-освітніх, соціяльноекономічних питань на території українських земель Наддніпрянщини, впроваджувати будь-які форми національного життя у правові рамки. Українська мова розцінювалася як “наріччя”, “відгалуження великоросійської мови” тощо, що вкорінювало ії статус меншовартости.

Тема боротьби за українську пресу на початку XX ст. є важливим ключем зрозуміти еволюцію змісту, шляхів і методів загального національно-визвольного руху, його соціяльно-структурних складників, а також програмних ідей, що їх об'єднували. Вона також яскраво демонструє суть централізаторської політики російської влади, котра лише під тиском наростання революційного руху 1905 р. пішла на незначні ліберальні поступки, також проголосивши свободу преси. Якщо звернутися до статистичних показників ситуації з україномовною пресою на початку XX ст. на території Наддніпрянщини, неважко зробити висновок про іiі катастрофічний стан. Наприклад, всього від часу зародження періодичного друку (в Одесі від 1809 р., Харкові - 1812 р., Києві- 1835 р., у більшості губерній - від 1838 р. від дати заснування офіційних “Губернских ведомостей”) до 1917 р. побачили світ понад три тисячі газет і журналів. При цьому відсоток україномовної преси становив $0,06 \%$. Співвідношення часописів офіційною російською і українською мовами мало такий вигляд: у Києві та Київській губернії - понад 800 і 95; в Одесі та Херсонській губернії - приблизно 800 і 12; Харківській - 340 і 14; Катеринославській - 267 і 10; Полтавській - 198 і 30; Подільській 113 і 3; Волинській - 107 і 3; Чернігівській - 90 і 3; Таврійській - 350 і $0^{8}$.

Представники національного руху великі сподівання покладали на Маніфест 17 жовтня 1905 р., який підписав імператор Микола II, та “Тимчасові правила про друк”. Однак по суті Емський указ повністю не скасували, і тому губернатори, які наділялися правом видавати свідоцтва на місцях, неохоче підтримували проєкти видання газет і журналів, особливо україномовних. Дослідник О. Сидоренко наводить численні приклади, як відхиляли клопотання в Одесі, Києві, Харкові та забороняли і закривали газети і журнали, які надрукували по кілька перших чисел: “Добра Порада”, “Вісти”, “Запоріжже”, "Слобожанщина”, "Народня Справа", “Боротьба"”. Серед видань, які спіткала доля закриття, була й перша україномовна газета на Лівобережній Наддніпрянщині “Хлібороб”. Побачили світ лише п’ять чисел цього видання, після чого його ініціяторів й видавців почали переслідувати та ув’язнювати.

${ }^{8}$ Потужна сила рідного слова, упоряд. Н.М. Сидоренко (Полтава: “РІК”, 2005), 9.

${ }^{9}$ Олександр Сидоренко, "Нездійснені проекти украӥнських часописів Полтавщини (19051907 рр.)” , у книзі Українська преса початку ХХ століття як націєтворчий чинник: Збірник наукових статей, відп. за вип. Микола Степаненко. (Полтава, 2006), 106 
ISSN 2078-6077. Наукові зошити історичного факультету Львівського університету. 2018-2019. Випуск 19-20. Proceedings of History Faculty of Lviv University. 2018-2019. Issue 19-20.

Заснування газети "Хлібороб” збіглося в часі з активізацією революційного руху в масштабах імперії. У місті Лубни революційні сили, репрезентовані українськими, російськими та єврейськими організаціями, восени 1905 р. створили Центральний комітет лубенських організацій, що за висновком поліції “поставив за мету своєї діяльності насильственне, шляхом збройного повстання, повалення встановленого в Російській імперії основними законами державного ладу i встановлення в Росії демократичної республіки" 10 . Прикметно, що Комітет зумів очолити протестний рух, і у грудні 1905 р. влада в місті фактично перейшла до його рук, виникла так звана “Лубенська республіка". У роботі комітету брали участь В. Шемет, М. Шемет, А. Лівицький, М. Бакайченко, М. Коренецький, Д. Піщанський та ін., яких згодом притягнули до судової відповідальности.

Заснування “Хлібороба" нерозривно пов'язане з лубенською родиною Шеметів, зокрема діяльністю братів Володимира та Миколи. Маючи університетську освіту, вони спільно з М. Поршем, В. Дорошенком, А. Лівицьким та ін. заснували в Лубнах громаду Революційної Української Партії та здобули високий авторитет не лише завдяки освіченості, але й повазі до української мови і традицій. Так колишній лубенець Павло Крат, який квартирував у будинку Шеметів, згадував: “. .. я мав нагоду познайомитися з Володимиром Шеметом, який хоч був з великих панів та студентом Київського університету, але ходив у селянській чумарці та сивій смушевій шапці, а розмовляв лише українською мовою. Він завжди казав: “На Україні хай кожний чужинець говорить по нашому, а як я поїду в його країну, там говоритиму по їхньому”" . Інший політичний діяч А. Жук називав В. Шемета "найактивнішим українцем у місті, що мав значний вплив на молодіж місцевих середніх шкіл та дрібне чиновництво". "На кожному кроці і на кожному місці, - писав далі А. Жук, - він маніфестував своє українство та одних цією національною активністю відпихав від себе, а других притягував" 12 . Микола Шемет був активним учасником підготови й організації відкриття пам'ятника I. Котляревському, побувавши у европейських країнах, ознайомився 3 іншими політичними цінностями. Обидва були симпатиками демократичних ідей. За твердженням одного з лідерів Української РадикальноДемократичної партії П. Стебницького, політичні погляди братів Шеметів і їхнього дітища газети “Хлібороб” стояли на програмових засадах цісї політичної сили. Однак дослідник В. Стрілець зазначав, що це не зовсім відповідає дійсності, оскільки газета відображала погляди й самостійницьких сил ${ }^{13}$. Зокрема активну

${ }^{10}$ Полтавщина. Історичний нарис, відп. за вип. О.М. Пустовгар. (Полтава: Дивосвіт, 2005), 179.

${ }^{11}$ Тарас Пустовіт, “Видавці Лубенського часопису "Хлібороб” у світлі архівних документів (1905-1908)”, у книзі Потужна сила рідного слова, упоряд. Н.М. Сидоренко. (Полтава: “РІКо, 2005), 352-353.

12 Там само, 353.

${ }_{13}$ Василь Стрілець, "Українська преса радикально-демократичного спрямування початку ХХ століття”, у книзі Украӥнська преса початку ХХ століття як націєтворчий чинник: Збірник наукових статей, відп. за вип. Микола Степаненко. (Полтава, 2006), 116. 
участь в національно-визвольному русі, і в підготові до видання часопису брав Микола Міхновський, який певний час жив і працював у Лубнах ${ }^{14}$.

Громадсько-політична активність братів Шеметів потребувала ширшої комунікації для пропаганди серед різних суспільних прошарків Полтавщини. Дізнавшись про “даровані” свободи слова й друку відповідно до Маніфесту 17 жовтня, Володимир Шемет 2 листопада 1905 р. телеграфом звернувся до голови Ради Міністрів Російської імперії з проханням дозволу видавати газету “Лубенщина". Як зазначають окремі дослідники, Володимир також мав намір видавати місцеву газету “Поступ”. Але відповіді на клопотання чи дозвіл він так і не отримав. Тоді ж, на власні кошти, нікого не спитавши, В. Шемет започаткував тижневик "Хлібороб"15. Володимир і Микола Шемети були не лише видавцями, але й авторами переважної більшости писаних матеріялів, редагували хроніку та дописи кореспондентів. Щоб усвідомити історичне значення тижневика "Хлібороб”, який виходив упродовж листопада - грудня 1905 р. й був заборонений після виходу п'ятого числа, важливо проаналізувати його зміст. Саме у статтях і публікаціях чітко простежується суспільно-політична спрямованість видання, його соціяльні пріоритети, протестні настрої, україноцентричний характер. Опрацювавши копії 2-5-го чисел "Хлібороба", визначимо й структуруємо певний комплекс ідей, які становили невирішене українське питання.

Видавці та їхні однодумці позиціонували газету передусім як “селянську часопись”, що цілком логічно випливає з соціяльної структури населення Полтавщини, домінанти питомої ваги в ній селянства, потреби захисту його соціяльно-економічних інтересів. У першому числі, що побачив світ 12 листопада 1905 р., було надруковане палке звернення від редакції до “. . . усіх прихильників народу, усіх, хто бажає щастя упослідженим, робочим людям, кличемо до спільної праці економічної та національної на користь рідного краю”. Метою видання оголошувалося “боротися за кращу долю хлібороба у згоді і поруч з міськими робітниками (пролетаріятом)" "16. Поза сумнівом можна стверджувати, що викладене кредо було суголосним громадсько-політичним ідеалам самих видавців. Завершується звернення прикрою констатацією: “Усі поспішають жити, усі працюють, не спочиваючи. А ми доси спимо. Життя не жде ледачих. Нумо ж до праці мерщій!” Отже, автори намагалися розбудити революційну енергію українців, спрямовуючи ії в усі сфери національного життя.

У цьому ж номері публікувалася велика стаття "Про вольності громадянські”, присвячена проблемі нищення української мови, що зрештою призвело до ситуації,

\footnotetext{
${ }^{14}$ Віра Жук, “Українські періодичні видання початку XX ст. (за даними посібників з історії України), Рідний край, № 2 (13), (2005), 135.

${ }^{15}$ Олександр Сидоренко, “Нездійснені проекти українських часописів Полтавщини (19051907 pp.)", у книзі Украӥнська преса початку ХХ століття як націєтворчий чинник: Збірник наукових статей, відп. за вип. Микола Степаненко. (Полтава, 2006), 106.

${ }^{16}$ Вибрані публікації. “Хлібороб” (1905). Редакційні статті”, у книзі Потужна сила рідного слова, упоряд. Н.М. Сидоренко, (Полтава: “РІК”, 2005), 18.
} 
ISSN 2078-6077. Наукові зошити історичного факультету Львівського університету. 2018-2019. Випуск 19-20. Proceedings of History Faculty of Lviv University. 2018-2019. Issue 19-20.

коли “. ...заборонено було цілому 30 -мільйонному народові українському вчитися і розвиватися на своїй рідній мові. Такого гніту, такої заборони не зазнавав і не зазнає, мабуть, ні один нарід на світі” ${ }^{17}$. Далі автори констатували, що довгоочікуваний царський Маніфест 17 жовтня “дарував усі народи ...усякими вольностями”, серед них і право використовувати рідне слово. Ці можливості доповнювалися й іншими демократичними свободами - недоторканістю особи, свободи зборів, організацій, совісті тощо. Цю статтю можна вважати концептуальною в розумінні видавцями історичних закономірностей і традицій української державности. Вони покликаються на досвід козацьких часів, виборність “. ... вільними голосами собі попів у церкві, полковників, усякий інший уряд військовий або рішати якісь інші громадські справи"18.

Редакційна стаття першого числа газети просякнута вірою у незворотність “дарованих" Маніфестом демократичних свобод: “І поворот тих вольностей народові $\epsilon$ великою перемогою народною, бо без вольностей тих ніяка людина чи бідна, чи багата, освічена чи неосвічена не може жити по людському, ось чому велика вага Маніфесту 17 падолиста". Їх складником також названо виборче право та право громадського контролю ${ }^{19}$.

Але ейфорія, викликана виходом Маніфесту, в ліберальних колах минула швидко. Видавці “Хлібороба" пильно відстежували поведінку влади в центрі й на місцях, і вже в 4-му числі у статті “ЗЗаходи проти волі” пишуть про посилення поліційно-жандармської сваволі й контролю за діяльністю громадських організацій, арешти, розчарування діяльністю Думи. Проблема політичного безправ'я народу, на їх думку, може вирішитися тільки тоді, коли “ . ...усі народи, що населяють Росію, не візьмуть вольності, доти й не матимуть нічого"20.

Володимир і Микола Шемети були представниками української політичної еліти, що сформувала власні соціяльно-політичні погляди під впливом i ліберальної, і революційної ідеології. То ж на сторінках тижневика публікували партійну хроніку, зокрема, про робітничі збори в Лубнах, скликані місцевою організацією Революційної Української Партії, з’їзд Української РадикальноДемократичної Партії ${ }^{21}$. Якщо РУП порушувала передусім питання соціяльного характеру - тривалости робочого дня, покращення умов праці, іiї оплати тощо, то УРДП, окрім питанню внутрішнього об'єднання, здебільшого вела мову про загальнодемократичні права, зокрема як засновувати культурні товариства, творити катедри “української мови, письменства та історії” у Київському, Харківському, Одеському університетах, організовувати “Просвіти” тощо.

${ }^{17}$ Вибрані публікації. “Хлібороб” (1905). Редакційні статті”, у книзі Потужна сила рідного слова, упоряд. Н.М. Сидоренко, (Полтава: “РІК”, 2005), 19.

${ }^{18}$ там само, 20.

19 Там само, 21.

${ }^{20}$ Хлібороб, число 4, (7 студня, 1905), 1.

${ }^{21}$ Там само, число 2, (20 грудня, 1905$), 3$. 
Провідне місце на шпальтах “Хлібороба” займала селянська проблематика. Зміст і структуру публікацій диктували нагальні невирішені питання, потреба самоорганізації селянства, боротьба за власні права і землю. Особливий інтерес викликала стаття В. Шемета про селянський з’їзд 10 грудня 1905 р. у Москві, де він згадує про участь делегатів від Полтавської, Чернігівської, Харківської губерній ${ }^{22}$. Якщо 3 резолюціями економічного характеру автор здебільшого солідаризується, високо оцінює спроби селянства самоорганізовуватись, то прикрим для нього фактом $є$ повне ігнорування багатонаціонального складу селянства: “. . . ніде, ні в одному пункті резолюції ні єдиним словом не згадується про те, що Росія складається не з одного народу... Шануючи дуже постанови з'їзду селянського у Москві - ми проте гадаємо, що на Україні земельне питання повинен розв 'язувати всеукраїнський селянський з'їзд, а його скликати повинна всеукраїнська спілка хліборобів"23.

Цінним джерелом уявлень про суспільно-політичні ідеали $є$ опубліковані в усіх числах "Хлібороба" “селянські присуди” або “приговори”. Ці колективні ухвали сільських або волосних сходів сприймаються як концентрована програма нереалізованих проблем. Так “Приговор Ковалівського волосного сходу Пирятинського повіту" вустами селян сформулював причини сільських негараздів і злиднів: “... головне лихо ми бачимо в тому, що не всі однаково володіють землею, а од землі ми тільки й живемо, що нас досі держать в темноті, бо досі не давали ніяких людських прав..."24. Селяни села Круглик Лубенського повіту запропонували ідею демократичного народоправства: “...щоб державою правили не чиновники, а виборні від народу люде, котрі добре знають наші потреби і те, як їм допомогти" 25 . Головною думкою всіх без винятку “селянських присудів" $є$ принцип передачі землі тим, хто іï обробляє.

Аграрне питання так і залишилося найгострішим для селянства. Разом 3 тим боротьбу за землю селяни тісно пов'язували з вимогою політичних прав для українців. Володимир Шемет, який був обраний депутатом Державної Думи від Полтавщини, з їі трибуни говорив: "У свідомості селянства України поняття “земля” нерозривно пов'язане 3 поняттям “воля” у розумінні широкої демократичної автономії для України... Земля і автономія тісно пов'язані 3 уявленнями про блага українського народу і з цим слід рахуватися при вирішенні такого питання як аграрне; слід мати на увазі, що Україна не лише частина держави, але і нація, і у значно більшій мірі нація, ніж частина держави. Лише тоді український народ буде вважати його вимоги задоволеними, коли буде мати можливість самостійно розпоряджатися своєю долею"26.

${ }^{22}$ Хлібороб, число 3, (28 грудня, 1905), 1.

${ }^{23}$ Там само, 1.

${ }^{24}$ Там само, 2.

${ }^{25}$ Там само, 2.

${ }^{26}$ Віктор Ревегук, Селянство Полтавщини в добу Украӥнської революції 1917-1921 рр. (Полтава: Полтавський літератор, 2017), 21-22. 
ISSN 2078-6077. Наукові зошити історичного факультету Львівського університету. 2018-2019. Випуск 19-20. Proceedings of History Faculty of Lviv University. 2018-2019. Issue 19-20.

Однією з головних ідей видавців “Хлібороба" був заклик до самоорганізації селянства. Третє число газети вмістило статтю “Заклик до селян”, де фактично пропонується альтернатива стихійним бунтам і погромам поміщицьких маєтків. Зазначалося, що “...гайдамацьким звичаєм не годиться робити та й небогато тим здобудемо, бо понасилають на нас військо, забране назад одберуть, ще й карають тяжко". Ефективнішою формою боротьби буде згуртованість, бо “громадою і з лихом легше боротись", а "хліборобів і робітників велика сила". Другою важливою ідеєю є переконаність у необхідності дієвих законів, за якими житиме суспільство: “А як будуть у нас такі закони, яких нам треба, то й біді нашій край прийде"27.

Видавці газети не лише констатували гостроту національного питання в Російській імперії, але й друкували матеріяли, що знайомили читачів 3 механізмами, як його вирішувати. Редакційна стаття "Про автономію", вміщена у числі п'ятому показує, що для Володимира та Миколи Шеметів оптимальною моделлю майбутнього устрою імперії є іiі демократизація з наданням автономії національним територіям і народам. Передчасно ідеалізуючи перспективи розвитку Росії як “вільної, молодої, свободолюбивоі”, в якій народ вже позбувся “гніту самодержавно-поліцейського", вони висували завдання “одночасного скасування також національного централізму, тобто гніту національного" 28 . Автори підкреслювали, що всі народи мають різний історичний досвід, культуру, традиції, які слід поважати центральній владі, враховувати природно-кліматичні відмінності територій і розвивати господарську спеціялізацію. Враховуючи всі відмінності, “не можна видавати однакових для всіх народів законів, бо умови життя, а разом з ними і потреби народні не однакові" 29 . Стаття завершувалася упевненістю, що “...такий великий край (Україна - Л. Б.) не тільки має право, але й повинен мати свою автономію”.

Видавцям додавало оптимізму надзвичайне для того часу піднесення національно-патріотичних настроїв. Їх засвідчили віча в Петербурзі та в українських містах. Особливо пафосно й піднесено описувалося Українське віче у Петербурзі, яке зібралося вперше "в межах Росії за 250 літ, себто за увесь той проклятий час, який перебувала Україна під тяжкою рукою Московської держави”зо. У цьому ж числі “Хлібороба” надруковане повідомлення про “3”їзд недержавних народів у Петербурзі”. Україну на ньому репрезентували Б. Грінченко, П. Жебунєв та І. Личко. Делегати дійшли висновку, що Росія мала б перетворитися на федерацію. Разом з тим на хвилі революційного піднесення учасникам з'їзду був притаманний романтизм та відсутність алгоритму практично втілити їхні мрії про вільне національне життя під “демократичним дахом" Росії.

${ }^{27}$ Хлібороб , (число 3 (28 грудня, 1905), 3.

${ }^{28}$ Хлібороб,(число 2 (20 грудня, 1905), 1.

${ }^{29}$ Там само, 1.

${ }^{30}$ Там само, (число 3, 1905), 1-2. 
До проблем як облаштувати національне життя, видавці повернулися у п’ятому числі часопису у статті “Як полагодити справи народів Російської держави”"31. Ї̈̈ можна кваліфікувати як розгорнутий план гармонізації відносин і між народами, і між центром та автономіями. Стаття містить також цифрові дані про народонаселення та національну структуру імперії. Так українці становили 25178100 осіб, обіймаючи другу сходинку після росіян, чисельність яких становила 62625900 осіб. Неодноразово газета нагадувала про досвід боротьби Фінляндії, народ якої рішучими кроками завоював собі право самоврядувати на власній території.

На сторінках числа четвертого порушувалося питання ролі політичної еліти суспільства - інтелігенції в консолідації суспільства, оскільки “нові політичні умови застали народню масу в стані дезорганізації”. Політичні організації, на думку видавців, мають прийти на зміну "хаотичному переходовому стану, який характеризується руїною, стіхійними, несьвідомими й часто жорстокими рухами народньої маси". Особливо допомоги інтелігенції потребували селяни в організації спілок і з'їздів ${ }^{32}$.

Емоційного забарвлення другому - п'ятому числам часопису надавали вірші. Вони публікувалися на першій сторінці й відразу привертали увагу читача. За змістом і духом вони були пронизані закликом пробуджуватись від політичної летаргії. У числі другому автор Яким Самотній ${ }^{33}$ у вірші з промовистою назвою "Не стогніть” звертався до читачів: "Хіба зменшаться лютії болі від покірливих сліз та ниття?" 34 . Цей же автор у п'ятому числі надрукував вірш "Прокидайтесь", де звертається із закликом: "Годі вже спати вам, заспані очі, иньші часи настають" ${ }^{35}$. Вірш під назвою “До дітей мого краю” належав Христі Алчевській. Ідеї іï твору суголосні попередньому і також починається словами "Не спи сину! - Час не спати". Вона вірить, що “І крізь хатнії віконця рознесеться, залунає, по занедбаному краю пісня Волі, пісня Сонця"з6.

Отже, аналіз окремих аспектів піднесення українського визвольного руху на початку XX ст. продемонстрував ознаки його організаційно-політичного згуртування, нові дієві форми поширювати національні ідеї, появу нового покоління українських політичних діячів 3 чітко окресленими суспільно-політичними ідеалами.

Істотним здобутком українців на початку XX ст. стало заснування україномовної періодики, пронизаної духом боротьби за соціяльні й національні права. Українська проблема стала головною у суспільно-політичній

\footnotetext{
${ }^{31}$ Хлібороб, (число 5, 1905), 1-2.

32 Там само, (число 4, 7 студня, 1905), 3.

${ }^{33}$ Під цим псевдонімом ховався Яким Єрмолаєв - див.: Дей О. І., Словник украйнських псевдонімів та криптонімів (XVI-XX cm.)(Київ: Наукова думка, 1969), 341.

${ }^{34}$ Там само, (число 2, 20 грудня, 1905), 1.

${ }^{35}$ Там само, (число 5, 16 студня, 1905), 1.

36 Там само, (число3, 28 грудня, 1905), 1.
} 
ISSN 2078-6077. Наукові зошити історичного факультету Львівського університету. 2018-2019. Випуск 19-20. Proceedings of History Faculty of Lviv University. 2018-2019. Issue 19-20.

спрямованості та змістовому наповненні першої газети-тижневика "Хлібороб”, що виходила українською мовою. Головні засади статті й висвітлюють процес боротьби за відміну заборон українських форм життя в українських землях у складі Російської імперії. Вирішена дослідницька проблема, поставлена авторкою - проаналізована роль першої україномовної газети в Наддніпрянській Україні "Хлібороб” у згуртуванні українського суспільства в національновизвольній боротьбі на початку ХX ст. задля розв' язку українського питання. Заборона тижневика свідчила про страх самодержавного режиму і перед послідовними борцями за українську справу Володимиром та Миколою Шеметами, і їхніми ідеями, викладеними на сторінках “Хлібороба”.

\title{
UKRAINIAN QUESTION IN THE “KHLIBOROB” ("PLOUGHMAN") NEWSPAPER
}

\author{
Ludmyla BABENKO \\ V.G.Korolenko Poltava National Pedagogical University \\ Department of History of Ukraine \\ Ostrohradskogo Street, 2, Poltava, 36000, Ukraine \\ e-mail: babenko_clio@ukr.net
}

The aim of this article is to show the process of struggle for elimination of Ukrainian forms of life ban in Ukraine in the structure of Russian Empire. The theme of the article is the role of the first Ukrainian-speaking in Central Ukraine newspaper "Khliborob" - "Ploughman" - in the process of Ukrainian society association in national-liberation struggle at the beginning of the XX century. This article covers events connected with Ukrainian-speaking mass media appearance at the beginning of the XX century. The author shows Russian autocracy policy aimed at the ban of national-liberation movement, which formed the "Ukrainian issue". The main point of the latter is unsolved complex of national, cultural, educational, socio-economic issues on the territory of Ukraine in the structure of Russian Empire. The Emsk Decree operated till 1905. It outlawed any forms of national life.

With the beginning of 1905 Revolution the national-liberation movement rise was observed. Revolutionary and civil organizations were established and activated in Poltava region. Revolutionary active was Lubny town, where the Lubny Organizations Central Committee appeared, which demanded the establishment in Russia the democratic republic. One couldn't imagine the struggle for democratic freedoms without free Ukrainian press. Such newspaper was the "Ploughman" in Lubny, Poltava region. Its editors were brothers Volodymyr and Mykola Shemet, who on the basis of the October 17, 1905 Tsar Law started the edition of the newspaper for their own money. There were only five publications of the newspaper, after that it was closed. Both editors were pursued and arrested.

The content of the "Ploughman" publications clearly showed the national-liberation movement politicalization, its differentiation to socialist and bourgeois-liberation directions, civil-political ideals formulation. The editors positioned their newspaper as the "rural publication". "Rural provisions" became the popular form of publications - so-called local programs, which reflected the rural vision of needed in agricultural sector changes. The "Ploughman" called rural population of Poltava region to self-organization, insisted that rural unions should be the hubs of struggle not only for economic, but also for political, national and cultural rights.

Among the priorities were the problem of the legal ban for the Ukrainian language. The actions of Ukrainians in different cities, in particular Ukrainian assembly in Petersburg, were widely highlighted. 
Their demands were supplemented with other democratic freedoms - personal immunity, freedom of assembly, organizations, liberty of conscience etc. The editors saw the solution of the national issue in granting autonomy to Ukraine in the structure of Russia in the context of its democratic restructuring. The authors of conceptual articles didn't demand full independence, this reflected political views of the most Ukrainian parties at those times. The editors condemned the facts of public events disruption, mass media closure etc. Thus the "Grain-Grower" newspaper played an important role in consolidation of civil-political power around the resolution of the Ukrainian issue.

So the "Ploughman" was the first Ukrainian-speaking newspaper in Central Ukraine, and it played the key role in the process of Ukrainian society consolidation at the beginning of the XX-th century. It became the printed organ, which attracted attention simultaneously to national, political, socio-economic, cultural and educational problems of Ukrainian society. This newspaper got all-Ukrainian character thanks to its editors', Volodymyr and Mykola Shemet, efforts. The imperial government's ban on the "Ploughman" newspaper edition showed the fear about the strengthening of national-liberation movement in Ukraine.

Keywords: "Ploughman" (Khliborob) newspaper, Volodymyr Shemet, Mykola Shemet, Lubny, Poltava region, press, censhorship.

\section{REFERENCES}

Vybrani publikatsii. "Khliborob" (1905). Redaktsijni statti, u knyzi Potuzhna syla ridnoho slova (Poltava: "RIK", 2005), 18-26.

Vira Zhuk, "Ukrajinski periodychni vydannja pochatku XX st. (za danymy posibnykiv z istorii Ukrainy)", Ridnyj Krai. Naukovyj, publitsystychnyj, hudozhnjo-literaturnyj almanakh. (Poltava: ASMI, 2005), 132-137.

Viktor Revehuk. Seljanstvo Poltavshchyny v dobu Ukrajinskoyi revolutsii 1917-1921 rr. (Poltava: Poltavskyj literator, 2017), 386.

Vasyl Strilets, "Ukrajinska presa radykalno-demokratychnogo sprjamuvannja pochatku XX stolittja”, u knyzi Ukrajinska presa pochatku XX stolitta jak natsijetvorchij chynnyk: Zbirnyk naukovyh statej, (Poltava, 2006), 115-119.

Taras Pustovit, "Vydavtsi Lubenskoho chasopysu Khliborob" u svitli arhivnyh dokumentiv (1905-1908)", u knyzi Potuzhna syla ridnoho slova (Poltava: "RIK", 2005), 359-358.

Poltavshchyna. Istorychnyj narys, (Poltava: Dyvosvit, 2005), $592+48$ vkl.

Oleksandr Sydorenko "Nezdijsneni proekty ukrayinskyh chasopysiv Poltavshchyny (19051907 rr.)", u knyzi Ukrajinska presa pochatku XX stolitta jak natsijetvorchyj chynnyk: Zbirnyk naukovyh statej, (Poltava, 2006), 105-108.

Oleksii Dey, Slownyk ukrayinskykh psevdonimiv ta kryptonimiv (XVI-XX-th) (Kyiv: Naukova dumka, 1969), 341.

Khliborob, №3, (28 hrudnja, 1905).

Khliborob, № 5, (16 studnja, 1905).

Khliborob, № 4, (7 studnja, 1905).

Khliborob, № 2, (20 hrudnja, 1905). 